\title{
Mostueatecine A and B: Two Indole Alkaloids and Mostueatecine C, One Triterpene from Mostuea batesii
}

\author{
Eric Gustave Gompe ${ }^{1}$, Blandine Marlyse Wache Ouahouo ${ }^{1}$, Pierre Mkounga ${ }^{1, *}$, \\ Merveille Tabouguia $^{2}$, Jules Clement Nguedia Assob ${ }^{2}$, Jean Fotie ${ }^{3}$, Augustin Ephrem Nkengfack ${ }^{1}$ \\ ${ }^{1}$ Department of Organic chemistry Faculty of Science University of Yaounde I, Yaounde, Cameroon \\ ${ }^{2}$ Department of Medical Laboratory Sciences, Faculty of health Sciences Laboratory, University of Buea, SW Region, Cameroon \\ ${ }^{3}$ Department of Chemistry and Physics Southeastern Louisiana University, Hammond, USA
}

Email address:

ericgustavegompebobda@yahoo.fr (E. G. Gompe), blysemar@yahoo.fr (B. M. W. Ouahouo), mpierrendi@yahoo.fr (P. Mkounga), tabouguiaoctavie@yahoo.fr (M. Tabouguia),juleclement@yahoo.fr (J. C. N. Assob), Jean.Fotie@selu.edu (J. Fotie), ankengf@yahoo.fr (A. E. Nkengfack)

${ }^{*}$ Corresponding author

\section{To cite this article:}

Eric Gustave Gompe, Blandine Marlyse Wache Ouahouo, Pierre Mkounga, Merveille Tabouguia, Jules Clement Nguedia Assob Jean Fotie, Augustin Ephrem Nkengfack. Mostueatecine A and B: Two Indole Alkaloids and Mostueatecine C, One Triterpene from Mostuea batesii. Journal of Diseases and Medicinal Plants. Vol. 2, No. 6, 2016, pp. 60-66. doi: 10.11648/j.jdmp.20160206.11

Received: July 19, 2016; Accepted: August 25 2016; Published: November 3, 2016

\begin{abstract}
Two new indole alkaloid derivatives namely Mostueatecine A (1), Mostueatecine B (2) and one new triterpene derivative Mostueatecine C (3) were isolated from the stem and leaves of Mostuea batesii, along with five known compounds: Camptothecine (4), $\beta$-amyrin-3-O-glucopyranoside (5), Oleanolic acid (6), 2 $\alpha, 3 \alpha, 19 \alpha$-trihydroxy-24-norurs-4(23),12-dien-28oic acid (7) and Saccharose(8). The structures of these compounds were elucidated using a detailed analysis of their HRESIMS, 1D and 2D NMR spectroscopic data. Some of these compounds were evaluated in vitro for their antimicrobial activities against a wide range of microorganisms. The results showed that none of them possess noticeable activity.
\end{abstract}

Keywords: Mostuea batesii, Loganiaceae, Indolic Alkaloids, Mostueatecine, Triterpenoids, Antimicrobial Activity

\section{Introduction}

The genus Mostuea belongs to the family of Loganiaceae and comprises many species among which most are present in Africa and Madagascar such as: M. batesii Baker, M. thomsonii. M. brunonis Didr, M. hiersuta, M. surinamensis Benth. and M. gabonica Baillon [1], and one species (Mostuea surinamenris) is common in northern part of South America.

The species Mostuea batesii grows primarily in the secondary rainforest, and is distributed in central Africa, from Cameroon through the south of the Central African Republic, Gabon and the Democratic Republic of Congo [2]. This plant is widely used in traditional medicine in most of these countries. Sure enough, grated roots of $M$. batesii are used in Gabon to dispel sleep or as an aphrodisiac, while in the Central African Republic, the roots decoctions are given to children as an anthelminthic [1]. This plant is also believed to possess hallucinogenic properties, and its prolonged use have been associated with cerebral disorder or schizophrenia $[3,4]$. Furthermore, experimentally, subcutaneous administration of theroot-bark extracts displayed a mean lethal dose of $0.25 \mathrm{~g} / \mathrm{kg}$ in mice, with death arising through a phase of hyperexcitability [1]. In anaesthetized dogs, an intravenous dose of up to $0.10 \mathrm{~g} / \mathrm{kg}$ produced hypertension, a short phase of tachycardia and hyperpnoea followed by cardiac and respiratory depression [1]. This might explain why the plant is also known as Mostuea stimulans A. [1].

Previous phytochemical screening of this species indicated the presence of indole alkaloids, $0.15 \%$ in the roots wood and $0.33 \%$ in the root bark, with the root bark alkaloids related to sempervirin and gelsemine [1]. Furthermore, several cytotoxic indole alkaloids including camptothecin $20-O-\beta$-Dglucoside, deoxypumiloside, strictosamide and 2'-Oacetylstrictosamide have been isolated from $M$. brunonis [5]. However, apart from the above mentioned studies, the 
chemical constituents of Mostuea batesii have not been studied enough to the best of our knowledge.

As part of a continuous effort to discover new antimicrobial antioxidant, anticancer, antimalarial and antiviral agents from Cameroonian medicinal plants, two new indole alkaloids, namely mostueatecine A (1), mostueatecine B (2) and a new triterpene mostueatecine C (3), together with five known compounds; Camptothecine(4), $\beta$-amyrin-3-Oglucopyranoside (5), Oleanolic acid (6), $2 \alpha, 3 \alpha, 19 \alpha$ trihydroxy-24-norurs-4(23),12-dien-28-oic $\operatorname{acid}(7)$ and Saccharose (8) have been isolated from M. batesii. In this paper, we report the isolation, structure elucidation of these compounds and evaluation of the antimicrobial activities of some of them.

\section{Results and Discussion}

The dried roots, leaves and stems of Mostuea batesii was extracted each with a methanol at room temperature. Filtration and vacuum concentration of the resulting solution led to dark greenish extract. Those crude extracts was subjected to silica gel column chromatography to give compounds 1-3 namely Mostueatecine A, B and C respectively along with five known compounds: camptothecine (4), $\beta$-amyrin-3-O-glucopyranoside (5), oleanolic acid (6), $2 \alpha, 3 \alpha, 19 \alpha$-trihydroxy-24-norurs-4(23),12dien-28-oic acid (7) and Saccharose (8).

Compound 1 was obtained as yellow powder from EtOAc/MeOH (2:8) fraction of the $\mathrm{MeOH}$ leaves crude extract of Mostuea batesii. It reacted positively to Dragendorff's reagent giving an orange color, suggesting that, this compound is an alkaloid. His molecular formula was determined to be $\mathrm{C}_{26} \mathrm{H}_{30} \mathrm{O}_{8} \mathrm{~N}_{2}$ from a pseudo molecular ion peak $[\mathrm{M}+\mathrm{H}]^{+}$at $\mathrm{m} / \mathrm{z} 499.3425\left(\mathrm{C}_{26} \mathrm{H}_{31} \mathrm{O}_{8} \mathrm{~N}_{2}\right)$ in the high resolution Electro Spray Ionization (HRESI). Thus compound 1 contains 13 double bond equivalents. The ${ }^{13} \mathrm{C}$ (table 1) and Distortionless Enhancement by Polarization Transfert (DEPT-NMR) Spectroscopy data of compound 1 showed two groups of carbon signals. The first one, contains 6 carbons signals all bearing an oxygen atom among which five methines and one methylene indicating that compound 1 possesses a sugar unit equivalent to glucopyranoside with $\beta$ configuration by the coupling constant $(7.3 \mathrm{~Hz})$ of the anomeric proton $[6,7]$. The second set has twenty carbons signals including 5 methylenes (among which one $\mathrm{sp}^{2}$ signal at $\delta_{C} 119$ and one oxygenated $\mathrm{sp}^{3}$ carbon signal at $\left.\delta_{C} 77.2\right), 8$ methines (one $\mathrm{sp}^{2}$ bearing on oxygen at $\delta_{C} 146.7$ ) and 7 quaternary carbon among which one lactam carbonyl at $\delta_{C} 163.3$ implying strictosamide skeleton for compound 1 [8]. The presence of the ABM aromatic coupling system indicates that ring $\mathrm{A}$ is 1, 2, 3-trisubstituted. According to this fact, the sugar moiety can be located on this ring. At this stage, his position can be on C-9 or C-12. This position was established using the $\mathrm{HMBC}$ correlation spectrum which showed on one hand, cross peaks between the aromatic triplet at $\delta_{H} 7.32$ and C-12 $\left(\delta_{C} 135.5\right)$ and C-8 $(118,6)$ and on the other hand, between the aromatic doublet at $\delta_{H} 7.23$ and the quaternary carbon $\mathrm{C}-13$ at $\delta_{C} 12126.9$, by this manner, the glucosyl moiety was connected to the aglycone at the position $\mathrm{C}-12$. Thus compound 1 was established to be C-12-Oglucopyranoside of Strictosamide to which the name Mostueatecine A was given.

Compound 2 was obtained as white needles from the EtOAc/MeOH(7:13) fraction of the $\mathrm{MeOH}$ crude extract of Mostuea batesii stems. The positive reaction to Dragendorff's tests reagent giving an orange color, indicated the alkaloid nature of compound 2. Its molecular formula $\mathrm{C}_{38} \mathrm{H}_{46} \mathrm{O}_{19} \mathrm{~N}_{2}$, was deduced from HRESI mass spectrum which exhibit the molecular ion pic at $\mathrm{m} / z 834.3456$ (calc $\mathrm{C}_{38} \mathrm{H}_{46} \mathrm{O}_{19} \mathrm{~N}_{2}$, 834.3426), corresponding to 17 degrees of insaturation. In accordance with its molecular formula, all the 38 carbons were well exhibited in the ${ }^{13} \mathrm{C}$ NMR spectrum (table 1) of compound 2, which were sortedby DEPT and HSQC experiments as two set of carbon signals. The first one contains twenty carbons signals including 3 methylenes (among which one $\mathrm{sp}^{2}$ signal at $\delta_{C} 118$ ), 6methines (one $\mathrm{sp}^{2}$ bearing an oxygen at $\left.\delta_{C} 103.9\right)$ and 10 quaternary carbon among which on lactam carbonyl at $\delta_{C} 163.8$ and one lactone carbonyl at $\delta_{C} 172.8$, implying naucleofficine B skeleton for compound 2 [9]. The second set has 18 carbons signals all bearing an oxygen atom among which 12 methines, 5 methylenes and one quaternary carbon indicating that compound 2 possess in his structure, three sugars unit. Between the 18 carbons signals: we have 2 anomerics carbons, among which one quaternary at $(\delta c 103.9)$ and one methyne at ( $\delta \mathrm{c} 97.3)$. The analysis of these 18 signals indicated that the tree sugar were constituted of one glucopyranosyl unit linked to the furanosyl moiety with the sequence $\beta$-D-furanosyl-(1-6)- $\beta$-D-glucopyranose, and one furanosyl unit [10]. The presence of the ABM aromatic coupling system indicatesthat ring $\mathrm{A}$ is 1,2,3-trisubstituted. In orderto give de position of these sugar moieties, we use the HMBC spectrum. The glucopyranosyl-furanosyl moiety is positioning at $\mathrm{C}-12$ in consideration of the HMBC correlation cross peaks which shows cross peaks between the anomeric proto $\mathrm{H}-1^{\prime}\left(\delta_{H} 5.81\right)$ and $\mathrm{C}-12\left(\delta_{C} 149.6\right)$ in one hand, and between the aromatic triplet at $\delta_{H} 8.15$ and $\mathrm{C}-12\left(\delta_{C} 149.6\right)$ and C-8 $\left(\delta_{C} 120.4\right)$, in the other hand. The remaining furanosyl moiety has been positioned at $\mathrm{C}-21$ regarding the HMBC cross peaks between $\mathrm{H}-21$ at $\delta_{H} 5.38$ and the oxymethylene of the furanosyl moiety at $\left(\delta_{C} 69.7\right)$.The proton and carbon signals of compound 2 (table 1) were assigned in detail according to analyses of ${ }^{1} \mathrm{H}-{ }^{1} \mathrm{H}$ COSY, HSQC, HMBC and comparison with reported values $[7,11]$ and was named Mostueatecine B.

Compound 3, was isolated as amorphous colorless powder from the mixture of $n$-Hexane-EtOAc (13:7). It showed positive control to the Lieberman-Burchard test suggesting that it is a triterpene. Its molecular formula, $\mathrm{C}_{30} \mathrm{H}_{44} \mathrm{O}_{6}$, corresponding to nine degree of unsaturation was deduced from HR-MS which showed in positive mode the protonated molecular ion peak $[\mathrm{M}+\mathrm{H}]^{+}$at $m / z$ 501.4266. The broad band decoupled ${ }^{13} \mathrm{C}$ NMR spectrum of this compound (table 1) exhibited 30 carbon signals, which were assigned with the 
assistance of HSQC and DEPT techniques as seven $s p^{3}$ methyl groups amongst which six appear as a singlet $\left(\delta_{\mathrm{C}} 16.7\right.$; $17.6,24.6 ; 26.3 ; 25.4$ and 27.9$)$, and one as a doublet at $\delta_{\mathrm{C}}$ 16.5 ; nine methine including two oxygenated $\mathrm{sp}^{3}$ methine $\left(\delta_{\mathrm{C}}\right.$ $68.7 ; 72.1)$ and three $\mathrm{sp}^{2}$ signals $\left(\delta_{\mathrm{C}} 127.2 ; 134.2 ; 138.4\right)$; five sp3 methylene. The remaining signals are those of quaternary carbon including two carbonyl, one attributed to a ketone moiety $\left(\delta_{C} 207.7\right)$, and the other to and acid group at $\left(\delta_{C}\right.$ 179.34) and one $\mathrm{sp}^{2} \mathrm{C}=\mathrm{C}$ signal at $\delta_{C}$ 141.1. All this data are in concordance with the $\alpha$-amyrine skeleton $[12,13]$.The presence of only one methyl doublet indicates that $\mathrm{C}-19$ was oxygenated. The position of the two $\mathrm{C}=\mathrm{C}$ double bonds was assigned to be $\Delta^{12}$ and $\Delta^{21}$, the ketone at $\mathrm{C}-3$, the acid group at position 28 and the two remaining hydroxyl groups were established to be at C-1 and C-11 respectively. This was done using HMBC and COSY correlations (figure 2) and biogenetic consideration. This compound was named Mostueatecine C.
All the solid compounds tested1-4, were active on at least six of the seven microbial strains with MICs ranging from $0.52 \mathrm{mg} / \mathrm{mL}$ to $33.33 \mathrm{mg} / \mathrm{mL}$. The most active was 4 with MICs ranging from $0.52 \mathrm{mg} / \mathrm{mL}$ to $16.67 \mathrm{mg} / \mathrm{mL}$. The MICs of gentamicin were ranging from 0.25 to $16 \mu \mathrm{g} / \mathrm{mL}$ and that which of fluconazole was $2 \mu \mathrm{g} / \mathrm{mL}$. All compounds presented a MICs values below $8 \mathrm{mg} / \mathrm{mL}$ on at least 2 strains demonstrating that each of them has antimicrobial properties according to [14], while 4 is noteworthy with two MICs values below $1 \mathrm{mg} / \mathrm{ml}$ on E. coli BL21 and on Candida krussei.

Liquid extracts presented MICs ranging from $2604 \mathrm{ppm}$ to $111111 \mathrm{ppm}$ as presented on table above demonstrating that these extracts showed moderate activities in accord with [15].

Overall, these results show that though all the compounds presented an activity against at least six of the seven tested pathogens, solid compound 4 had more interesting activities.

Table 1. ${ }^{1} \mathrm{H}$ and ${ }^{13} \mathrm{C}$ NMR data for compounds 1,2 and 3 in DMSO ( $\delta$ in ppm).

\begin{tabular}{|c|c|c|c|c|c|c|}
\hline \multirow[b]{2}{*}{$\mathbf{P}$} & \multicolumn{2}{|c|}{ Compounds 1} & \multicolumn{2}{|c|}{ Compounds 2} & \multicolumn{2}{|c|}{ Compounds 3} \\
\hline & $\delta_{C}$ & $\delta_{H}$ & $\delta_{C}$ & $\delta_{H}$ & $\delta_{C}$ & $\delta_{H}$ \\
\hline 1 & $\mathrm{NH}$ & $10.98(1 \mathrm{H}, \mathrm{s})$ & $\mathrm{NH}$ & $12.13(1 \mathrm{H}, \mathrm{s})$ & 45.3 & $2.10 ; 1,75(2 \mathrm{H}, \mathrm{dd}, 12,0 ; 10,03 \mathrm{~Hz} ; 10.3,6.5 \mathrm{~Hz})$ \\
\hline 2 & 134.4 & $/ /$ & 125.2 & $/ /$ & 72.1 & $3.82,(1 \mathrm{H}, \mathrm{ddd}, 11.5,8.5,4.2 \mathrm{~Hz})$ \\
\hline 3 & 52.5 & $4.88(1 \mathrm{H}, \mathrm{t}, 12,0 \mathrm{~Hz})$ & 140.2 & $/ /$ & 207.7 & $/ /$ \\
\hline 4 & & $/ /$ & & & 41,2 & // \\
\hline 5 & 42.3 & $4.46(2 \mathrm{H}, \mathrm{t}, 6,5 \mathrm{~Hz})$ & 47.3 & $4.52(2 \mathrm{H}, \mathrm{t}, 6,6 \mathrm{~Hz})$ & 50.6 & $1.62(1 \mathrm{H}, \mathrm{m})$ \\
\hline 6 & 20.5 & $3.14(2 \mathrm{H}, \mathrm{t}, 6,5 \mathrm{~Hz})$ & 28.1 & $3.20(2 \mathrm{H}, \mathrm{t}, 6,6 \mathrm{~Hz})$ & 19.3 & $1.52 ; 1.25(2 \mathrm{H}, \mathrm{m})$ \\
\hline 7 & 108,3 & // & 112.8 & // & 35.3 & $1.49 ; 1.24(2 \mathrm{H}, \mathrm{m})$ \\
\hline 8 & 126.9 & // & 120.4 & // & 28.2 & // \\
\hline 9 & 117.5 & $7.08(1 \mathrm{H}, \mathrm{d}, 7,9 \mathrm{~Hz})$ & 97.6 & $7.51(1 \mathrm{H}, \mathrm{d}, 8,1 \mathrm{~Hz})$ & 47.3 & $2.71(1 \mathrm{H}, \mathrm{s})$ \\
\hline 10 & 120.8 & $7.32(1 \mathrm{H}, \mathrm{t}, 7,9 \mathrm{~Hz})$ & 124.7 & $8.15(1 \mathrm{H}, \mathrm{t}, 8,1 \mathrm{~Hz})$ & 24.6 & // \\
\hline 11 & 107.4 & $7.23(1 \mathrm{H}, \mathrm{d}, 7,9 \mathrm{~Hz})$ & 118.1 & $7.53(1 \mathrm{H}, \mathrm{d}, 8,1 \mathrm{~Hz})$ & 62.7 & $3.6,(1 \mathrm{H}, \mathrm{m})$ \\
\hline 12 & 135.5 & // & 149.6 & // & 127.2 & $4.98(1 \mathrm{H}, \mathrm{m})$ \\
\hline 13 & 118.6 & // & 140.2 & // & 141.1 & $/ /$ \\
\hline 14 & 25.5 & $1.93 ; 2.44(2 \mathrm{H}, \mathrm{m})$ & 94.7 & $7.02(1 \mathrm{H}, \mathrm{s})$ & 55.5 & $1.93(1 \mathrm{H}, \mathrm{t})$ \\
\hline 15 & 42.8 & $2.45(1 \mathrm{H}, \mathrm{m})$ & 145.1 & $/ /$ & 25.4 & $1.43 ; 1.16(2 \mathrm{H}, \mathrm{m})$ \\
\hline 16 & 98.8 & // & 108.8 & // & 46.9 & $1.64 ; 1.39(2 \mathrm{H}, \mathrm{t})$ \\
\hline 17 & 146.7 & $7.34(1 \mathrm{H}, \mathrm{s})$ & 172.8 & $/ /$ & 37.5 & // \\
\hline 18 & 119.8 & $4.79 ; 4.92(1 \mathrm{H}, \mathrm{t}, 12,4)$ & 118.2 & 4. $79(1 \mathrm{H}, \mathrm{t}, 12,6 \mathrm{~Hz})$ & 53.6 & $3.50(1 \mathrm{H}, \mathrm{s})$ \\
\hline 19 & 133.3 & $6.95(1 \mathrm{H}, \mathrm{m})$ & 124.7 & $7.45(1 \mathrm{H}, \mathrm{m})$ & 76.1 & $/ /$ \\
\hline 20 & 42.8 & $2.59(1 \mathrm{H}, \mathrm{m})$ & 23.6 & $3.60(1 \mathrm{H}, \mathrm{m})$ & 45.1 & $2.21(1 \mathrm{H}, \mathrm{d}, 6,3 \mathrm{~Hz})$ \\
\hline 21 & 77.2 & $4.58(1 \mathrm{H}, \mathrm{m})$ & 103.9 & $5.38(1 \mathrm{H}, \mathrm{d}, 12,2 \mathrm{~Hz})$ & 138.4 & $5.30,(1 \mathrm{H}, \mathrm{t}, 6,2 \mathrm{~Hz})$ \\
\hline 22 & 163.3 & $/ /$ & 163.8 & $/ /$ & 134.1 & $5.25(1 \mathrm{H}, \mathrm{d} 6,4 \mathrm{~Hz})$ \\
\hline 23 & & & & & 24.1 & $1.21(3 \mathrm{H}, \mathrm{s})$ \\
\hline 1 ' & 95.6 & $5.59(1 \mathrm{H}, \mathrm{m})$ & 102.7 & $5.81(1 \mathrm{H}, \mathrm{m})$ & 24.6 & $1.22(3 \mathrm{H}, \mathrm{s})$ \\
\hline $2^{\prime}$ & 72.6 & $2.99(1 \mathrm{H}, \mathrm{m})$ & 70.4 & $3.01(1 \mathrm{H}, \mathrm{m})$ & $17.6\left(\mathrm{C}_{25}\right)$ & $1.16(3 \mathrm{H}, \mathrm{s})$ \\
\hline 3 ' & 69.8 & $3.09(1 \mathrm{H}, \mathrm{m})$ & 74.1 & $3.15(1 \mathrm{H}, \mathrm{m})$ & $16.5\left(\mathrm{C}_{26}\right)$ & $0.93(3 \mathrm{H}, \mathrm{s})$ \\
\hline $4^{\prime}$ & 76.7 & $3.15(1 \mathrm{H}, \mathrm{m})$ & 76.3 & $3.18(1 \mathrm{H}, \mathrm{m})$ & $16.7\left(\mathrm{C}_{27}\right)$ & $0.98(3 \mathrm{H}, \mathrm{s})$ \\
\hline 5 , & 60.8 & $3.12 ; 3,18(2 \mathrm{H}, \mathrm{m})$ & 60.3 & $3.13 ; 3.17(2 \mathrm{H}, \mathrm{m})$ & $179.3\left(\mathrm{C}_{28}\right)$ & $11.97(1 \mathrm{H}, \mathrm{s})$ \\
\hline 6' & 77.2 & $3.56(1 \mathrm{H}, \mathrm{m})$ & 77.2 & $3.56(1 \mathrm{H} \mathrm{m})$ & $26.9\left(\mathrm{C}_{29}\right)$ & $1.31(3 \mathrm{H}, \mathrm{s})$ \\
\hline $1 "$ & & & 103.9 & $/ /$ & $16.5\left(\mathrm{C}_{30}\right)$ & $1.13(3 \mathrm{H}, \mathrm{s})$ \\
\hline $2 ”$ & & & 76.9 & $3.19(1 \mathrm{H}, \mathrm{m})$ & & \\
\hline $3 "$ & & & 72.7 & $3.11(1 \mathrm{H}, \mathrm{m})$ & & \\
\hline $4 "$ & & & 82.4 & $3.66(1 \mathrm{H}, \mathrm{m})$ & & \\
\hline $5 "$ & & & 61.9 & $3.14 ; 3.17(2 \mathrm{H}, \mathrm{m})$ & & \\
\hline $6 "$ & & & 62.1 & $3.15 ; 3.19(2 \mathrm{H}, \mathrm{m})$ & & \\
\hline $1 "$ & & & 69.7 & $3.81 ; 3.77(2 \mathrm{H}, \mathrm{m})$ & & \\
\hline $2 "$, & & & 102.8 & $3.48(1 \mathrm{H}, \mathrm{m})$ & & \\
\hline $3 "$ & & & 76.9 & $3.71(1 \mathrm{H}, \mathrm{m})$ & & \\
\hline $4 " ”$ & & & 71.5 & $3.81(1 \mathrm{H}, \mathrm{m})$ & & \\
\hline $5, "$ & & & 82.4 & $3.89(1 \mathrm{H}, \mathrm{m})$ & & \\
\hline $6 "$ & & & 60.9 & $3.81 ; 3,77(2 \mathrm{H}, \mathrm{m})$ & & \\
\hline
\end{tabular}


<smiles>C=CC1COC=C2C(=O)N3CCc4c([nH]c5c(OC6OC(CO)C(O)C(O)C6O)cccc45)C3CC21</smiles>

1

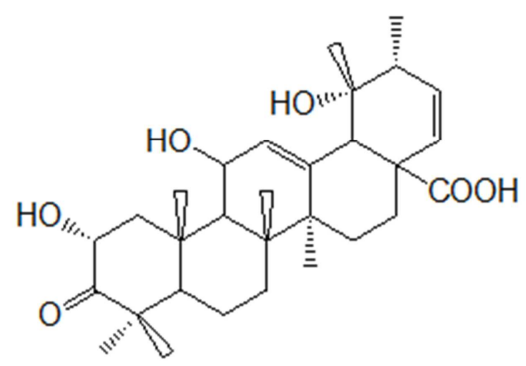

3

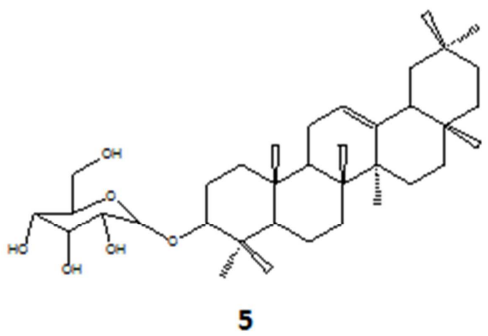

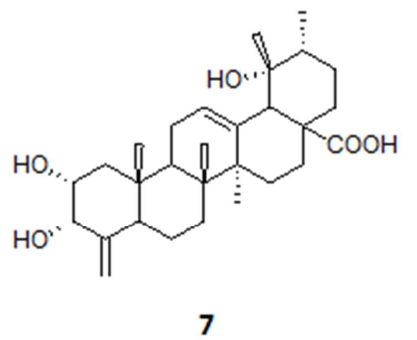<smiles>C=CC1c2cc3n(c(=O)c2C(=O)OC1OCC1OC(CO)C(O)C1O)CCc1c-3[nH]c2c(OC3OC(CO)C(OC4(CO)OC(CO)C(O)C4O)C(O)C3O)cccc12</smiles>

2<smiles>CCC1(O)C(=O)OCc2c1cc1n(c2=O)Cc2cc3ccccc3nc2-1</smiles>

4

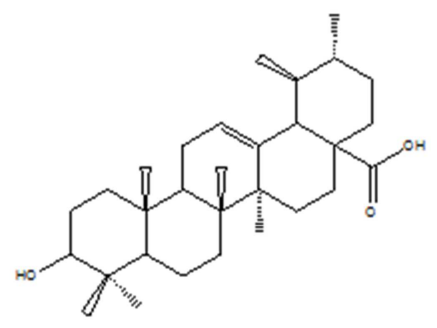

6<smiles>OCC1OC(OC2(O)OC(CO)C(O)C2O)C(O)C(O)C1O</smiles>

Figure 1. Structures of compounds 1-8.

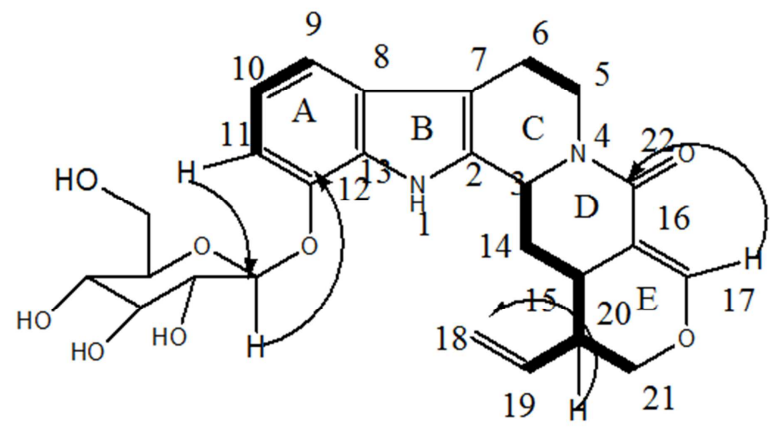

$\underset{\mathrm{HMBC}}{\mathrm{COSY}}$

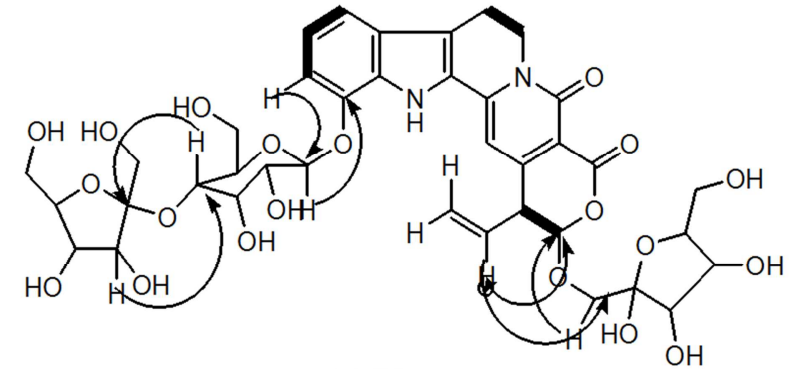

$\overbrace{}^{\mathrm{COSY}}$ 


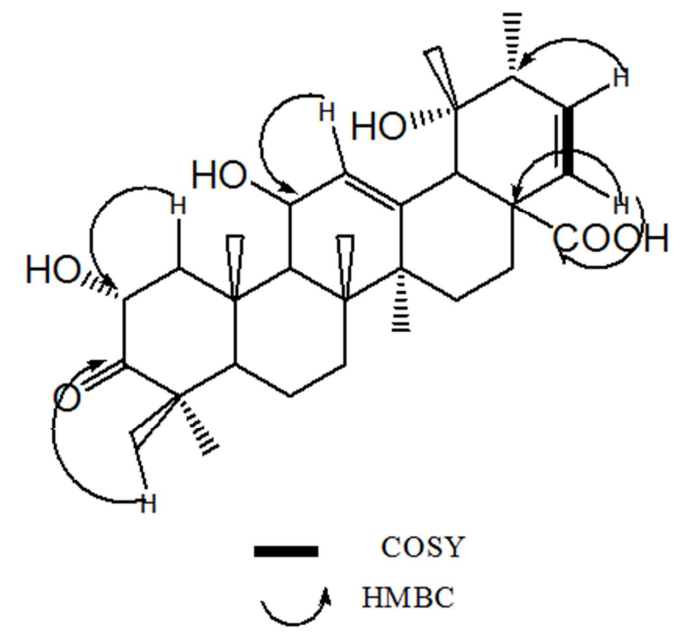

Figure 2. Key COSY and HMBC correlations for compounds 1, 2 and 3.

Table 2. Minimal Inhibitory Concentrations (MICs) and Microbicidal concentrations (MMCs) of solid extracts in mg/mL.

\begin{tabular}{|c|c|c|c|c|c|c|c|c|}
\hline & & $\begin{array}{l}\text { Escherichia } \\
\text { coli }\end{array}$ & $\begin{array}{l}\text { Escherichia coli } \\
\text { BL21 }\end{array}$ & $\begin{array}{l}\text { Providencia } \\
\text { stuartii }\end{array}$ & $\begin{array}{l}\text { Pseudomonas } \\
\text { aeruginosa }\end{array}$ & $\begin{array}{l}\text { Staphylococcus } \\
\text { aureus }\end{array}$ & $\begin{array}{l}\text { Candida } \\
\text { krussei }\end{array}$ & $\begin{array}{l}\text { Cryptococcus } \\
\text { laurentii }\end{array}$ \\
\hline \multirow{2}{*}{1} & MIC & 15.55 & 15.55 & 7.77 & 7.77 & 7.77 & 3.89 & 3.89 \\
\hline & MMC & ND & ND & 15.55 & 15.55 & 15.55 & 15.55 & 3.89 \\
\hline 2 & MMC & ND & 3.33 & ND & 13.33 & ND & 13.33 & 6.66 \\
\hline \multirow{2}{*}{3} & MIC & 33.33 & 16.67 & 33.33 & 8.33 & 4.16 & 4.16 & 8.33 \\
\hline & MMC & ND & ND & ND & 33.33 & 8.33 & 8.33 & 16.67 \\
\hline 4 & MMC & 33.33 & 1.04 & 33.33 & ND & 16.67 & 1.04 & 16.67 \\
\hline$(+)$ & MIC & 0.5 & 4 & 16 & 2 & 0.25 & 2 & NT \\
\hline$\mu \mathrm{g} / \mathrm{ml}$ & MMC & 0.5 & 4 & 32 & 2 & 0.25 & 4 & \\
\hline$(-)$ & MIC & ND & ND & ND & ND & ND & ND & ND \\
\hline
\end{tabular}

$(+)$ : positive control: gentamicin for bacteria and fluconazole for yeast

(-) negative control: DMSO 40\%

ND: not determined, the concentration is higher than the highest concentration of the experiment. NT: not tested.

\section{Experimental Section}

General experimental procedures:

The chemical constituents of Mostua batesii were purified using open column chromatography (CC Merck; Kiesegel 60); and thin layer chromatography (Alu Gram R; SIL G/ $\mathrm{UV}_{254}$ silica gel plates Merck) by using gradient of $n$ Hexane-EtOAc and EtOAc-MeOH. MS and HRMS were obtained on a GC-17A, GCMS-QP5050 Shimadzu mass spectrometer. ${ }^{1} \mathrm{H},{ }^{13} \mathrm{C}$ NMR spectra as well as $2 \mathrm{D}$ NMR experiments were recorded in DMSO in a JEOL ECX 500 spectrometer. Chemical shifts are expressed in part per million $(\delta)$ relative to TMS as internal standard.

The samples were tested on seven pathogens: one reference strain (Escherichia coli BL21) and six clinical strains distributed as follow: three Gram negative (Escherichia coli, Providencia stuartii, and Pseudomonas aeruginosa) one Gram positive (Staphylococcus aureus) and two yeasts (Candida krusei and Cryptococcus laurentii). The table below shows the concentration at which the compounds were tested. Liquid samples are reported in ppm (parts per million)

Table 3. Table of concentrations.

\begin{tabular}{llll}
\hline Compound & Volume or mass of Compound & Total volume of solvent added (40\%DMSO) & Concentration of stock solution \\
\hline 1 & $70 \mathrm{mg}$ & $1.5 \mathrm{ml}$ & $46.67 \mathrm{mg} / \mathrm{ml}$ \\
2 & $40 \mathrm{mg}$ & $1 \mathrm{ml}$ & $40 \mathrm{mg} / \mathrm{ml}$ \\
3 & $100 \mathrm{mg}$ & $1 \mathrm{ml}$ & $100 \mathrm{mg} / \mathrm{ml}$ \\
4 & $0.5 \mathrm{ml}$ & $1 \mathrm{ml}$ & $333333 \mathrm{ppm}$ \\
\hline
\end{tabular}

Biological activities: Both solid and liquid extracts were tested by broth micro-dilution assay according to the procedure below.

The broth micro dilution technique gives information on the activity of the compounds and extracts through the determination of the Minimum inhibitory concentration (MIC) that inhibits microbial growth. The assay was performed according to the procedure described by Njimoh and collaborators [15] using 96-well plates. All the 96 wells of the microplate were filled with $100 \mu \mathrm{L}$ of culture medium 
(5\% glucose and $1 \%$ phenol red-supplemented nutrient broth). After filling each well with $100 \mu \mathrm{L}$ of broth, $100 \mu \mathrm{L}$ of each sample (compound, or reference antibiotics) previously diluted in DMSO (40\%) was added to the first well of each microtiter line; giving a total volume of $200 \mu \mathrm{L}$. After thorough mixture, successive two fold serial dilutions were performed by transferring $100 \mu \mathrm{L}$ of the mixture from the first to the eleventh well. An aliquot $(100 \mu \mathrm{L})$ was discarded from the eleventh well. The twelfth well served as control since no sample (compound, or reference antibiotics) was added in it. Finally, $50 \mu \mathrm{L}$ of the microbial suspension at $10^{6} \mathrm{CFU} / \mathrm{ml}$ was added in each test well. Tests were incubated aerobically at $37^{\circ} \pm 0.1^{\circ} \mathrm{C}$ for 24 and 48 hours for bacteria and yeast species respectively. Visual observation of growth was based on the colour change of the phenol redindicator from red to yellow depicting acid waste produced by the growth of the microorganism. The concentration of the well containing the lowest sample concentration that prevented visible growth or change in colour was considered the MIC. To further ascertain the MIC and to determine the Minimun Microbicidal Conentration (MMC), $10 \mu \mathrm{L}$ of the content of the well with the MIC and the two preceding ones were used to inoculate solid agar plates. After 24 hours (for bacteria) and 48 hours (for fungi) incubation at $37^{\circ} \mathrm{C}$, the well with the least growth was considered to be the MMC. The table 2 above shows the MICs and the MMCs of the compounds that were obtained.

Plant material: Botanical material Mostua batesii (Loganiaceae) was collected in January 2014 in Yaoundé, Center Region of Cameroon. A voucher specimen was authenticated by M. NANA plant taxonomist and deposited at the National Herbarium of Cameroon (HNC 38660).

Extraction and isolation: The root, the stem and leaf of this plant were chopped separately, air dried and crushed to afford respectively $1,048 \mathrm{~kg}, 2 \mathrm{~kg}$ and $836 \mathrm{~g}$ of Mostua batesii (root, stem and leaf) powder. All of these powders were extracted respectively by maceration at room temperature with $\mathrm{MeOH}$ and concentrated to dryness in vacuum to yield oily material respectively $90 \mathrm{~g}, 95 \mathrm{~g}$ and $46 \mathrm{~g}$. These extract were then subjected to column chromatography eluting with gradient of $n$-Hexane- EtOAc and EtOAc-MOH, respectively monitored by means of TLC.

The extract of stem rich in triterpenes was identified using the Liebermann-Burchar reagent and alkaloid was identified by TLC using and the Dragendorf and Valser-Mayer spray reagent. $80 \mathrm{~g}$ of this extract was submitted to column chromatography (CC) and eluted with gradient $n$-HexaneEtOAc. These procedures yielded pure Oleanolic acid 5 (1, $85 \mathrm{~g}, 20 \% n$-Hexane/EtOAc), pure $2 \alpha, 3 \alpha, 19 \alpha$ - trihydroxy24- nurs-4(23), 12-dièn-27-oic acid 7 (0, 89 g 35\% $n$ Hexane/EtOAc), and one pure new indolic alkaloid Mostueatecine A, compound 1 (1, 3 g 20\% EtOAc/MeOH).

The extract of leaf rich in triterpenes and alkaloid were identified by TLC using the Liebermann-Burchar and the Dragendorf and Valser-Mayer spray reagent. This extract was submitted to column chromatography (CC) and eluted with gradient $n-H e x a n e-E t O A c$, these procedures yielded pure $\beta$ -
D-glucopyranosyloxytriterpenoid5 $\quad(0,98 \quad$ g $\quad 70 \% \quad n$ Hexane/EtOAc), one triterpenoid $3(0,98$ g $65 \%$ nHexane/EtOAc), and one pure new indolic alkaloid Mostueatecine B compound 2. (1,05g 35\%EtOAc/MeOH).

The extract of root rich in alkaloid was identified by TLC using the Dragendorf and Valser-Mayer spray reagent. This extract was submitted to column chromatography (CC) and eluted with gradient $n$-Hexane- EtOAc as eluent to yield, give one pure quinoleic alkaloid compound 4camptothecine (25 mg, 45\% $n$-Hexane/ EtOAc), and 55 subfractions. These subfractions with similar TLC profiles were combined to give 5 series $\left(\mathrm{S}_{1}-\mathrm{S}_{5}\right) . \mathrm{S}_{5}(4,6 \mathrm{~g})$ was subjected to silica gel $\mathrm{CC}$ with a mixture of $\mathrm{n}-\mathrm{Hexane} / \mathrm{EtOAc}$ as eluent to yield one pure sugar compound 8 (1,5g, 70\% n-Hexane/EtOAc).

Camptothecine 4: was obtained as a yellow powder ${ }^{13} \mathrm{C}$ NMR spectroscopic data (DMSO, $400.131 \mathrm{MHz}) \delta_{\mathrm{C} .} 152.6$ (C-1) 147.5 (C-3); 50.3(C-5); 129.8 (C-6); 131.6 (C-7) 129.0(C-8) 127.9(C-9); 127.7(C-10); 130.4 (C-11); 128.5 (C12); 150.0(C-13); 96.7(C-14) 147.9(C-15), 119.1(C-16), 156.9 (C-16a), 65.3(C-17), 7.8(C-18), 30.3(C-19), 72.4(C20) $172.5(\mathrm{C}-21) .{ }^{1} \mathrm{H}$ NMR spectroscopic data (DMSO, 500 $\mathrm{MHz}) \delta_{\mathrm{H}} .5 .27(2 \mathrm{H}, \mathrm{s} \mathrm{H}-5), 8.67(1 \mathrm{H}, \mathrm{s}, \mathrm{H}-7) 8.13(1 \mathrm{H}, \mathrm{d}, 8 \mathrm{~Hz}$ H-9) $7.84(1 \mathrm{H}, \mathrm{t}, 8.8 \mathrm{~Hz}, \mathrm{H}-10) 7.86(1 \mathrm{H}, \mathrm{t}, 8.8 \mathrm{~Hz}, \mathrm{H}-11) 8.18$ $(1 \mathrm{H}, \mathrm{d}, 8 \mathrm{~Hz}, \mathrm{H}-12) 7.33$ (1H,s H-14), 5.41 (2H, s, H-17), 0.88 (3H, t, 8Hz, H-18), 1.92 (2H, dq, 8 Hz, H-19), 6.52 $(1 \mathrm{H}, \mathrm{s}, \mathrm{OH})$.

Amorphous powder $5,{ }^{13} \mathrm{C}$ NMR spectroscopic data (DMSO, 400,131 MHz) $\delta_{\mathrm{C}} 33.20(\mathrm{C}-1), 25.3$ (C-2), 77.2 (C3), 55.4 (C-4), 20.4 (C-5), 36.1 (C-6), 41.7 (C-7), 55.4 (C-8), 49.6 (C-9), 36.1 (C-10), 22.9 (C-11), 121.1 (C-12), 140.3 (C12), 31.3 (C-14), 29.1 (C-15), 31.2 (C-16), 35.3 (C-17), 56.1 (C-18), 45.3 (C-19), 49.1 (C-20), 27.6 (C-21), 28.6 (C-22), 18.5(C-23), 18.75 (C-24), 19.7 (C-25), 31.3(C-26), 28.7( C27) 18.9 (C-28), 11.7 (C-29 ), 11.5 (C-30), 100.7 (C-1'), 73.2 (C-2'), 76.7 (C-3'), 69.8(C-4'), 76.7 (C-5'), 60.9 (C-6'). ${ }^{1} \mathrm{H}$ NMR spectroscopic data (DMSO, $500 \mathrm{MHz}) \delta_{\mathrm{H} .} 1.31$ and 1.01 (2H, m H-1), 1.17 (2H,m, H-2), 3.11 (1H,m,H-3), 1.01 and $1.8(2 \mathrm{H}, \mathrm{t}, \mathrm{H}-4), 1.49(1 \mathrm{H}, \mathrm{m}, \mathrm{H}-5), 1.03$ and $1.82(2 \mathrm{H}, \mathrm{m}$, H-6), 0.87 (1H,m H-8), 0.84, (1H, m, 1H-9), 1.52 and 1.61 (2H, m, H-11), 5.32 (1H,d, H-12), 1.42 (1H, m, H-14), 1.50 and $1.63(2 \mathrm{H}, \mathrm{m}, \mathrm{H}-15), 1.51$ and $1.91(2 \mathrm{H}, \mathrm{m}, \mathrm{H}-16)$, 1.27(1H,d,H-17), 1.21 (1H, d, H-18), 1.93 (2H, d,H-19), 1.88 $(2 \mathrm{H}, \mathrm{t}, \mathrm{H}-20), 1.92(2 \mathrm{H}, \mathrm{t}, \mathrm{H}-21), 0.63(3 \mathrm{H}, \mathrm{s}, \mathrm{H}-22), 0.69(3 \mathrm{H}$, s, H-23), 0.84 (3H, s, H-24), 0.92 (3H, s H-25), 0.94 (3H,s H26), 0.82 (3H,s, H-27) 0.62( $3 \mathrm{H}, \mathrm{s} \mathrm{H}-29) 0.77$ (3H,s H-30) 5.44 (1H,d, H-1'), 3.13 (1H, m, H-2'), 3.01 (1H,m, H-3'), 2.99 ( 1H,m, H-4'), 3.22 (1H,m, H-5'), 3.02 (2H, m, H-6').

Oleanolic acid6. ${ }^{13} \mathrm{C}$ NMR spectroscopic data (DMSO, 400,131 MHz) $\delta_{\mathrm{C}} 39.8(\mathrm{C}-1), 27.8$ (C-2), 79.6 (C-3), 39.9 (C4), 56.7 (C-5), 19.4 (C-6), 34.3 (C-7), 40.7 (C-8), 47.6 (C-9), 38.1 (C- 10), 24.3 (C-11), 126.8 (C-12). 139.6 (C-13), 42.8 (C-14), 29.2 (C-15), 25.3 (C-16), 47.6 (C-17), 54.3 (C-18), 40.4 (C-19), 40.4 (C-20), 31.7 (C-21), 38.1 (C-22), 28.7 (C23), 16.0 (C-24). 16.3 (C-25), 17.6 (C-26), 24.0 (C-27) 181.6 (C-28), 17.8 (C-29), 21.5 (C-30). ${ }^{1} \mathrm{H}$ NMR spectroscopic data (DMSO, $500 \mathrm{MHz}) \delta_{\mathrm{H}} 5.21$ (IH m, H-12), 3.14 (IH m, H-3), $2.20(\mathrm{IH}, \mathrm{d}, \mathrm{J} 18,19=11.3 \mathrm{~Hz}, \mathrm{H}-18), 2.02-1.15(2 \mathrm{H}, \mathrm{m}, \mathrm{H}-$ 
22), 1.10 (s, 3H, H-23), 0.96 (3H s, H-27), 0.95 (3H s, H26), 0.93 (3H s, H-24), 0.87 (3H d, H-29), 0.83 (3H d, H-30), $0.76(3 \mathrm{H}, \mathrm{s}, \mathrm{H}-25)$.

$2 \alpha, 3 \alpha, 19 \alpha$ - trihydroxy-24- nurs-4(23), 12-dièn-27-oic 7: Amorphous powder, ${ }^{13} \mathrm{C}$ NMR spectroscopic data (DMSO, $400,131 \mathrm{MHz}) \delta_{\mathrm{C} .} 37.5(\mathrm{C}-1), 72.5(\mathrm{C}-2), 78.2(\mathrm{C}-3), 150.4$ ( C4), 49.9 (C-5) 31.3 (C-6) 46.9 (C-7), 39.7 (C-8), 41.6 (C-9), 37.9 (C-10), 20.9 (C-11) 128,00 (C-12), 138.90(C-13), 41.47 (C-14), 25.2(C-15), 24.2 ( C-16), 47.8 (C-17), 53.8 (C-18) 72.1 (C-19), 41.6(C-20), 25.8 (C-21), 28.9 (C-22) 103.7 (C23) 13.8(C-25) 15.2(C-26), 16.1(C-27), 180.8 (C-28), 23.4 (C-29), 25.6 (C-30). ${ }^{1} \mathrm{H}$ NMR spectroscopic data (DMSO, $500 \mathrm{MHz}) \delta_{\mathrm{H} .} 1.76 ; 1.67(2 \mathrm{H}, \mathrm{t}, \mathrm{H}-1), 3.45(1 \mathrm{H} \mathrm{d}, \mathrm{J}=1, \mathrm{H}-2)$, $3.75(1 \mathrm{H}, \mathrm{d} \mathrm{H}-3), 2.05$ (1H, d, H-5), 1.52; 1.56 (2H,t, H-6), $1.10 ; 2.04(2 \mathrm{H}, \mathrm{t}, \mathrm{H}-7), 2.17(1 \mathrm{H}, \mathrm{s}, \mathrm{H}-9), 2.06(1 \mathrm{H}, \mathrm{s}, \mathrm{H}-11)$ 5.33(1H,s, H-12), 1.22 and $2.34(2 \mathrm{H}, \mathrm{dt}, \mathrm{H}-15), 2.05$ and 3.12(2H, dt, H-16), 2.53 (1H, s, H-18), 1.52(1H, s, H-20), 1.35 and $2.10(2 \mathrm{H}, \mathrm{t}, \mathrm{H}-21), 2.05$ and $2.18(2 \mathrm{H}, \mathrm{t}, \mathrm{H}-22) 4.74$ and $5.22(2 \mathrm{H}, \mathrm{s}, \mathrm{H}-23), 0.80(3 \mathrm{H}, \mathrm{s}, \mathrm{H}-25), 0.95(1 \mathrm{H}, \mathrm{s}, \mathrm{H}-$ 26 ), 0.86 (1H,s, H-27), 1.06 (3H, s, H-29), 1.26 (3H, s H-30) $4.92 \mathrm{~s}(\mathrm{OH}-19)$.

Saccharose 8 yellow powder. ${ }^{13} \mathrm{C}$ NMR spectroscopic data (DMSO, 400,131 MHz) $\delta_{\mathrm{C}} .92 .1(\mathrm{C}-1), 71.7(\mathrm{C}-2), 72.8(\mathrm{C}-3)$, 70.0(C-4), 82.6(C-5), 62.1(C-6), 62.2(C-1'), 104.1(C-2'), 77.0(C-3'), 74.3(C-4'), 72.9(C-5'), 62.1(C-6'). ${ }^{1} \mathrm{H}$ NMR spectroscopic data (DMSO, $500 \mathrm{MHz}) \delta_{\mathrm{H} .} 5.18(1 \mathrm{H}, \mathrm{m}, \mathrm{H}-1)$, $3.17(1 \mathrm{H}, \mathrm{m}, \mathrm{H}-2), 5.04(1 \mathrm{H}, \mathrm{d}, \mathrm{O}-\mathrm{H}-2), 3.47$ (1H,m,H-3), 4.78 $(1 \mathrm{H}, \mathrm{d}, \mathrm{OH}-3,5 \mathrm{~Hz}), 3.09(1 \mathrm{H}, \mathrm{m}, \mathrm{H}-4), 4.74(1 \mathrm{H}, \mathrm{d}, \mathrm{OH}-4$, $5 \mathrm{~Hz}), 3.62$ (1H, m, H-5), $3.54(2 \mathrm{H}, \mathrm{d}, \mathrm{H}-6,5 \mathrm{~Hz}), 4.41$ $(1 \mathrm{H}, \mathrm{t}, \mathrm{OH}-6,5 \mathrm{~Hz}), 3.38$ (2H, d, H-1', 6Hz), 4.80 (1H, t, OH1' $6 \mathrm{~Hz}), 3.87$ (1H, t, H-3', 8Hz), 4.49 (1H,d, OH-3' 5Hz), 3.751 (1H, q, H-4', 9Hz), 5.16 (1H, d, OH-4,' 4Hz), 3.64(1H, m, H-5') 3.57 (2H, d,H-6', 5Hz) 4.37 (1H, t, OH-6', 5Hz).

\section{References}

[1] Schmelzer, G. H.;Gurib-Fakim, A. Medicinal Plant 1: Plant Resources of Tropical Africa 11 (1). PROTA Foundation/Backhuyspublishers. Wageningen, Nertherlands, 385-388. 2008.

[2] Burkill, H. M.The useful plants of West Tropical Africa. 2nd Edition.Volume 3, Royal Botanic Gardens, Kew, Richmond, United Kingdom. 8571995.

[3] De Smet, P. A. G. M.Some ethnopharmacological notes on African hallucinogens. Journal of Ethnopharmacology. 50: 141-146. 1996.
[4] Neuwinger, H. D.; African traditional medicine: a dictionary of plant use and applications. Med. Pharm. Scientific, Stuttgart, Germany. 589. 2000.

[5] Dai, J. R.; Hallock, Y. F.; Cardellina, J. H.; Boyd, M. R.; 20O-ßGlucopyranosylcamptothecin from Mostueabrunonis: A potential camptothecin pro-drug with improved solubility. $J$. Nat. Prod. 62: 1427-1429, 1999.

[6] Dzoyem, J. P.; Tangmouo, J. G.; Lonsi, D.; Etoa, F. X.; Lohoue, P. J.; In vitro. Antifungal Activity of extract and plumbagin from Diospyros crassIfloraHiern (Ebenaceae) Phytoter. Res. 14: 1122007.

[7] Sun, Y. N.; Wang, C. L.; Zhang, N.; Wang, Z.; Liu, Z. L.; Liu, J. L.; Synthesis of tetrahydro- $\beta$-carbolinesfromphthalic anhydrides and tryptamineChinese Chemical Letters 25. 1503-1506. 2014

[8] Xuan, W. D.; Chen, H. S.; Du, J. L.; Liang, S.; Li, T. Z.; Cai, D. G.; Two new indole alkaloids from Nauclea officinalis. Journal of Asian Natural Products Research; 8: 719-722. 2008.

[9] Sun, J.; Lou, H.; Dai, S.; Xu, H.; Zhao, F.; Liu K. indole alkaloids from Nauclea officinalis with weak antimalarial activity. Phytochemistry 69, 1405-1419. 2007.

[10] Wang, M.; Kikuzaki, H.; Csiszar, K.; Boyd, C. D.; Maunakea, A.; Fong, S. F.; Ghai, G.; Rosen, R. T.; Nakatani, N.; Ho, C. T.Novel trisaccharide fatty acid ester identified from the fruits of Morinda citrifolia (Noni). J. Agric. Food Chem., 47(12): 4880. 1999.

[11] Noaki, K.; Hideki, O.;Fukushi, E.; Shuichi, O.; Kawa, J. Structural analysis of two trisaccharides isolated from fermented beverage of plant extract, Open Geoscience 1. 2530. 2008 .

[12] Rao, S. C.; Banji1, D.; Sandhya, S.; Mahesh, V. A study on the nutraceuticals from the genus Rumex Hygeia. J. D. Med. 3 (1), 2011, 76- 88 .

[13] Mahato, S. B; andKundu, A. P. ${ }^{13} \mathrm{C}$ NMR spectra of pentacyclic triterpenoids a compilation and some salient features. Phytochemistry. 37, (6), 1517-1575. 1994.

[14] Fabry, W.; Okemo, P. O.; Ansorg, R. Antibacterial activity of East African medicinal plants. Journal of Ethnopharmacology. 60: 79-84. 1998.

[15] Njimoh, D. L.; Assob, J. C.; Mokake, S. E.; Nyahalah, D. J.; Yinda, C. K.; Sandjon, B. Antimicrobial activities of a plethora of medicinal plant extracts and hydrolates against human pathogens and their potential to reverse antibiotic resistance. International Journal of Microbiology: 15. 2015. 